\title{
A Comparison Between Raw Material and Technologies for a Sustainable Biodiesel Production Industry
}

\author{
Jorge Mario Marchetti \\ Av. Alem 1251. Departamento de Física. Instituto de Física del Sur (IFISUR), \\ Universidad Nacional del Sur - CONICET \\ Bahía Blanca, \\ Argentina
}

\section{Introduction}

Biodiesel is a renewable liquid biofuel produced from renewable lipid sources such as vegetable oils or animal fats. It results from the transesterification reaction of triglycerides with an alcohol in the presence of a catalyst; see Figure 1 (Marchetti et al., 2007, Srivastava \& Prasad, 2000, Ma \& Hanna, 1999).

The transesterification reaction is a series of reactions where from triglycerides diglycerides are produced, from these ones monoglycerides are produced and finally, from these monoglycerides glycerol is produced. In all these steps, fatty acid alkyl ester (biodiesel) is formed.

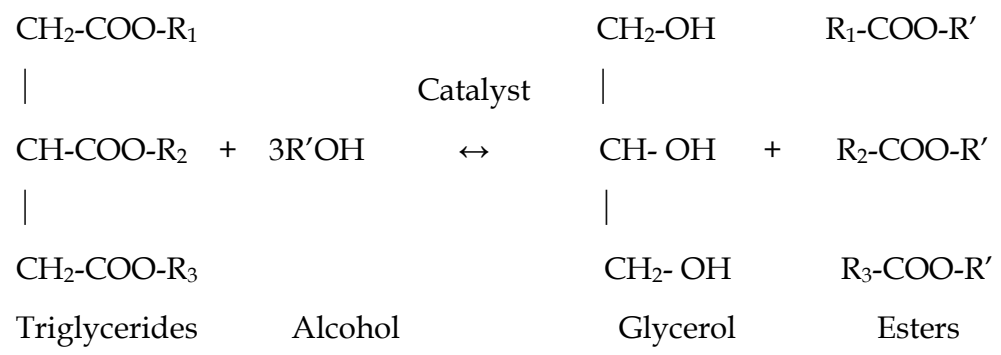

Fig. 1. Typical transesterification reaction: a triglyceride with an alcohol to produce biodiesel. ( $\mathrm{R}_{\mathrm{n}}$ are carbon chain of different length)

This reaction is most commonly catalyzed by a homogeneous base catalyst that could be sodium hydroxide among others. However, to be able to use this type of catalyst, the raw material needed is a refined vegetable oil. If more impure oil is used together with some free fatty acids and sodium hydroxide in it, the fatty acid involved in the saponification reaction will consume the catalyst. The soap produced will also be a problem for the downstreaming separation of the biodiesel and the glycerol. The saponification reaction could be seen in Figure 2 (Marchetti et al., 2007, Srivastava \& Prasad, 2000, Ma \& Hanna, 1999, Fukuda et al., 2001, Knothe et al., 2005, Marchetti, 2010). 


\begin{tabular}{|c|c|c|c|c|c|c|}
\hline $\mathrm{R}-\mathrm{COOH}$ & + & $\mathrm{NaOH}$ & $\leftrightarrow$ & $\mathrm{H}_{2} \mathrm{O}$ & + & $\mathrm{R}-\mathrm{COO}-\mathrm{Na}$ \\
\hline Fatty acid & & Base & & Water & & Soap \\
\hline
\end{tabular}

Fig. 2. Saponification reaction of free fatty acid and sodium hydroxide

In order to avoid this problem, the technological solutions put forward were: the use of homogeneous acidic catalysts such as sulfuric acid (Knothe et al., 2005, Marchetti, 2010, Schuchardt et al., 1998, Noureddini \& Zhu, 1997, Freedman et al., 1984, Zheng et al., 2006, Canakci \& Van Gerpen, 2003a, 2003b), solid catalysts such as zeolites, solid resins (basic as well as acid) (Bournay et al., 2005, Di Serio et al., 2005, 2006, Soriano et al., 2009, Hamad et al., 2008, Suppes et al., 2004, Kulkarni et al., 2006, López et al., 2008, Cao et al, 2008), enzymatic technologies (Bajaj et al., 2010, Ranganathan et al., 2008, Antczak et al, 2009, Rodrigues et al., 2008, Dalla Rosa et al., 2008, Matassoli et al., 2008), supercritical alcohols (Demirbaş, 2002, 2003, Saka \& Kusdiana, 2001, Kusdiana \& Saka, 2001, 2004, Hawash et al., 2009, Gui et al., 2008, Kasim et al. 2009), membrane reactors (Dubé et al. 2007, Baroutian et al., 2011, Zhu et al., 2010, Cheng et al., 2010, Cao et al., 2008), monolithic reactors (Kolaczkowski et al., 2009, Dizge et al., 2009, Tonetto \& Marchetti, 2010), etc.

All these technological solutions have many advantages over each other but also some drawbacks due to different considerations; for instance, reaction time, reaction temperature, operational cost, amount of equipment, quality of the final product, complexity of purification, and so forth (Srivastava \& Prasad, 2000, Ma \& Hanna, 1999,Marchetti, 2010, Schuchardt et al., 1998).

Furthermore, all these new technologies have a real advantage: they can be used for treating less pure raw materials, allowing a higher presence of free fatty acids and, in some cases, the presence of water. This is pertinent not only to the increasing Food vs. Fuel debate, but also to the one about how the vegetable oil we produce should be used. By applying these technologies, typical pollutants can be consumed, and crude oil, waste, as well as frying oil, soapstocks, and the like, can be used as raw materials for Biodiesel production. As a result, all the refined oil could be left for human consumption.

There is a need of knowing more about the different biodiesel technologies based on the type of raw materials they are able to treat. This work aims to shed light on the subject by presenting a comparison of the different qualities of vegetable oils, comparing the physicalchemical properties of these oils, and their influences over the final biofuel.

\section{Global situation of the vegetable oil market}

Since the beginning of the 19th century, people have used vegetable oils and animal fats based on the knowledge storage over centuries and not so much on the scientific knowledge as it are today; based on their structure, physical properties, etc. The need of understanding and knowing more about the vegetable oil arises due to the increasing value of this product as for example in its use in medicine, cosmetics as well as for fuel for lighting.

Normally, vegetable oils are obtained from different plants seeds, such as sunflower, peanut, coconut, palm, palm kernel, soybean, corn, and many other options. To chose from which of these vegetables produce the oil depends on several factors, some of them are the location of the landscape, the climate of the region, the nutrients of the soil as many other environmental as well as economic variables (it is also important which oil has a better market to be sold). Based on some types of seeds, O'Brien et al. 2000, have done a 
compilation showing where some of the main seeds are being cultivate around the world. An extraction from their work it could be seen in Table 1.

\begin{tabular}{|c|c|c|}
\hline Seed & Amount of oil (\%) & Productive areas \\
\hline Canola & $40-45$ & $\begin{array}{l}\text { Canada, China, India, France, Austria, United Kingdom, } \\
\text { Germany, Poland, Denmark, Check Republic. }\end{array}$ \\
\hline Corn & 3.1-5.7 & $\begin{array}{l}\text { USA, Mexico, Russia, Belgium, France, Italy, Germany, } \\
\text { Spain, United Kingdom. }\end{array}$ \\
\hline Cotton & $18-20$ & $\begin{array}{l}\text { China, Russia, USA, India, Pakistan, Brazil, Egypt, } \\
\text { Turkey. }\end{array}$ \\
\hline Peanut & $45-50$ & $\begin{array}{l}\text { China, India, Nigeria, USA, Senegal, South Africa, } \\
\text { Argentina }\end{array}$ \\
\hline Crocus & $30-35$ & China, USA, Spain, Portugal \\
\hline Soybean & $18-20$ & USA, Brazil, Argentina, China, India, Paraguay, Bolivia \\
\hline Sunflower & $35-45$ & $\begin{array}{l}\text { Russia, Argentina, Austria, France, Italia, Germany, Spain, } \\
\text { United Kingdom. }\end{array}$ \\
\hline Coconut & $65-68$ & $\begin{array}{l}\text { Filipinas, Indonesia, India, México Sri Lanka, Thailand, } \\
\text { Malaysia, Vietnam, Mozambique, New Guinea, Republic } \\
\text { of Côte d'Ivoire }\end{array}$ \\
\hline Olive & $15-35$ & $\begin{array}{l}\text { Spain, Italy, Italia, Greece, Tunes, Turkey, Morocco, } \\
\text { Portugal, Syria, Algeria, Yugoslavia, Egypt, Israel, Libya, } \\
\text { Jordan, Lebanon, Argentina, Chile, Mexico, Peru, USA, } \\
\text { Australia. }\end{array}$ \\
\hline Palm & $45-50$ & $\begin{array}{l}\text { Malaysia, Indonesia, China, Filipinas, Pakistan, México, } \\
\text { Bangladesh, Colombia, Nigeria, Republic of Côte d'Ivoire }\end{array}$ \\
\hline Palm kernel & $44-53$ & $\begin{array}{l}\text { Malaysia, Indonesia, China, Filipinas, Pakistan, México, } \\
\text { Bangladesh, Colombia, Nigeria, Republic of Côte d'Ivoire }\end{array}$ \\
\hline
\end{tabular}

Table 1. Mayor producer for several vegetable oils (O'Brien et al., 200).

In Table 1 it is presented the mayor regions where different oils are being produced as well as the percentage of oil in each seed. It could be seen that even when each seed produce different amounts of oil, there are several of them that produce an amount between 30 and $53 \%$.

Even more, the price of vegetable oil has become quite volatile over the last year (www.indexmundi.com (a)). In Figure 3 it can be seen the fluctuation of prices for soybean oil for the last 30 years (www.indexmundi.com (b)). In the case of soybean oil, there is a major peak in June 2008, (where the price of the soybean oil have reached values of 1414 US\$)

The soybean oil situation is similar to that of the major oils such as sunflower, coconut, rapeseed, palm, palm kernel, olive, etc., being the case presented in Figure 3 just as an example. It is also important to notice that the evolution of the vegetable oil prices is link directly to the prices of petroleum oil. Figure 4 shows the evolution of the petroleum prices as well as the price of the soybean oil. When petroleum prices increases there is an increase in soybean oil; however, the increases in soybean oil are not only associated to petroleum crisis. 


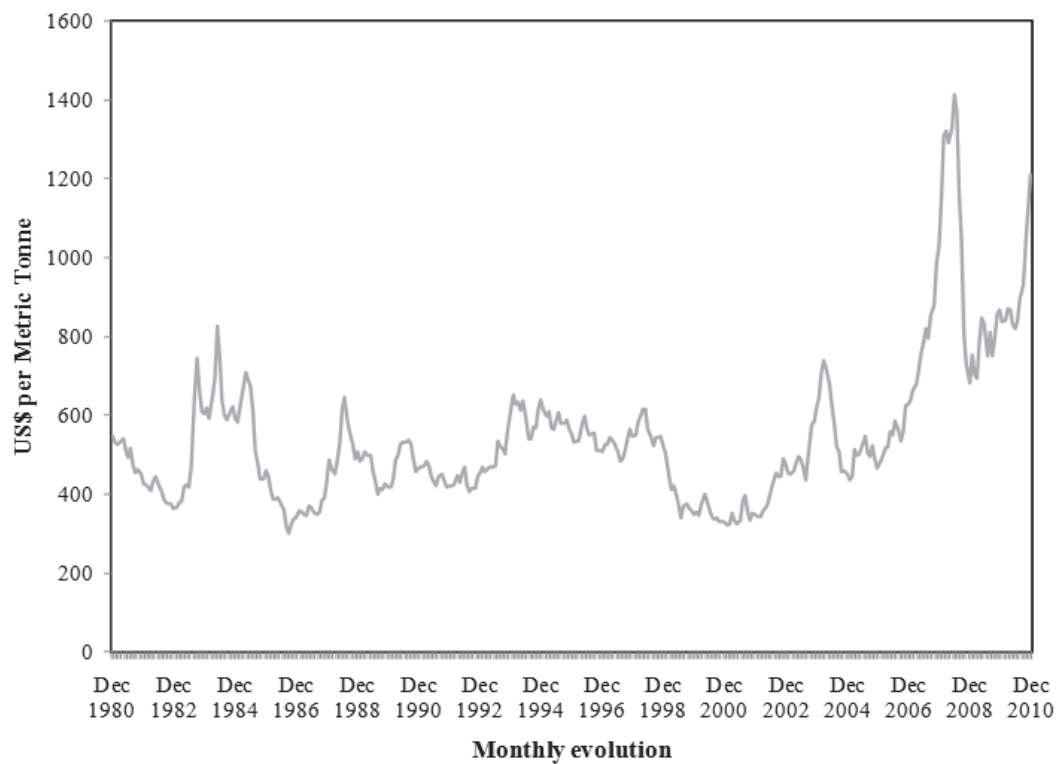

Fig. 3. Monthly evolution of the price for soybean oil over the last 30 years (www.indexmundi.com (a)).

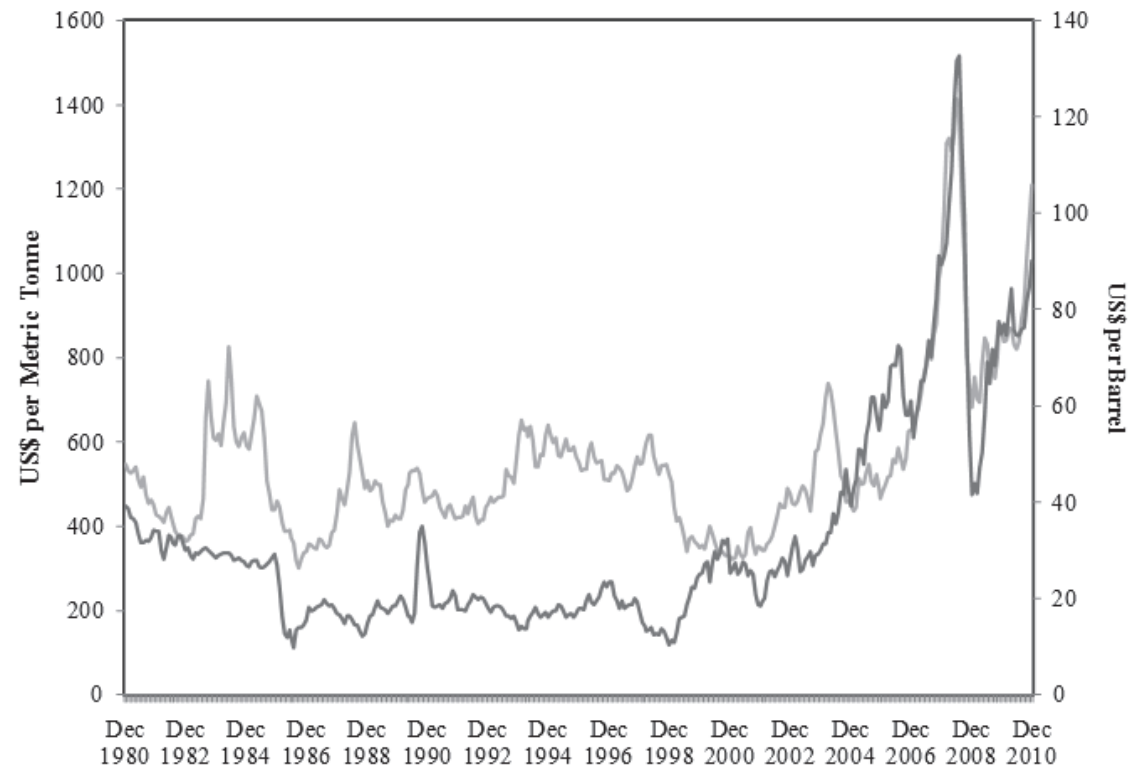

Monthly evolution

Fig. 4. Monthly evolution of the price for soybean (--) and petroleum (-) oil over the last thirty years (www.indexmundi.com (b)). 


\section{Vegetable oil: types and composition}

Due to the different origin of the vegetable oils, their structure and composition vary from one to another, mainly in the length of the hydrocarbon chain, as well as in the amount and location of the double bonds. O'Brien et al., (O'Brien et al., 2000) have performed a comparison with some of the main types of oil and the percentage of the different types of fatty acids involves. Table 2, extracted from reference O'Brien et al., 2000 shows these percentages.

As it could be seen from Table 2, the main composition fatty acid compositions of the vegetable oils is generally based on a C18 carbon length, with one or two double bonds, this is the case for corn, cottonseed, peanut, rapeseed, soybean and sunflower. For crambe oil, the main contribution is by C22:1. However, the second and third most abundant fatty acid is different from oil to oil. It is important to point out that, even thought there are differences in the fatty acid composition of different oils, the major participations are always from carbon chain with double bonds

\begin{tabular}{lccccccccc}
\hline \multirow{2}{*}{ Vegetable oil } & \multicolumn{8}{c}{ Fatty acid composition \% by weight } \\
\cline { 2 - 10 } & $\mathbf{1 6 : 1}$ & $\mathbf{1 8 : 0}$ & $\mathbf{2 0 : 0}$ & $\mathbf{2 2 : 0}$ & $\mathbf{2 4 : 0}$ & $\mathbf{1 8 : 1}$ & $\mathbf{2 2 : 1}$ & $\mathbf{1 8 : 2}$ & $\mathbf{1 8 : 3}$ \\
\hline Corn & 11.67 & 1.85 & 0.24 & 0.00 & 0.00 & 25.16 & 0.00 & 60.60 & 0.48 \\
Cottonseed & 28.33 & 0.89 & 0.00 & 0.00 & 0.00 & 13.27 & 0.00 & 57.51 & 0.00 \\
Crambe & 20.7 & 0.70 & 2.09 & 0.80 & 1.12 & 18.86 & 58.51 & 9.00 & 6.85 \\
Peanut & 11.38 & 2.39 & 1.32 & 2.52 & 1.23 & 48.28 & 0.00 & 31.95 & 0.93 \\
Rapeseed & 3.49 & 0.85 & 0.00 & 0.00 & 0.00 & 64.4 & 0.00 & 22.30 & 8.23 \\
Soybean & 11.75 & 3.15 & 0.00 & 0.00 & 0.00 & 23.26 & 0.00 & 55.53 & 6.31 \\
Sunflower & 6.08 & 3.26 & 0.00 & 0.00 & 0.00 & 16.93 & 0.00 & 73.73 & 0.00 \\
\hline
\end{tabular}

Table 2. \%wt. of the different fatty acid in the main types of oil. (O'Brien et al., 2000)

The diverse composition of the different types of oil also affects their main physicalchemical properties due to the carbon length and the double bonds. Table 3 presents some major properties for 6 typical types of vegetable oil.

It could be seen that in some cases the properties values are quite similar; that is the case of the specific gravity and the smoke point. On the other hand the flash point is quite diverse, changing from $225^{\circ} \mathrm{C}$ to $327^{\circ} \mathrm{C}$. Another property that has a wider range is the acid value, going from 0.6 to 6.6 accordingly.

So far, it has been presented the properties of refine oils. However, as it will be point out later in this chapter, the need for a less pure raw material, and therefore cheaper, is imperative. The main possibilities are frying, waste, cooking oils, soapstocks as well as oil from algae and non edible oils. The first four options are considered waste. On the other hand, the oil from algae is not a waste but could be considered as non edible oil.

Table 4 shows some of the main properties of refined, crude and waste oil to compare the different types of oil. There, it is clear that the sulfur content increases considerably when comparing refined oil with waste oil. Similar results could be found when comparing the acid value.

On the other hand, the viscosity values do not change that much due to the presence of impurities.

Among the non edible oils, Table 5 shows the variation of some parameters for 4 types of non edible oils. 


\begin{tabular}{lccc}
\hline \multicolumn{1}{c}{ Property } & Refine [*] & Crude [+] & Waste [x] \\
\hline Kinematics viscosity & 30.2 & 36 & 40.2 \\
{$\left[\mathrm{~mm}^{2} / \mathrm{s}\right]$} & 0.24 & 0.278 & 0.18 \\
Carbon residue [wt\%.] & 38.01 & 39 & -- \\
Cetane number & 39.41 & 39.2 & 24.67 \\
Higher heating value & 0.012 & 0.01 & --- \\
[MJ/kg] & 0.013 & 0.075 & 5 \\
Ash content [wt\%] & 112.86 & 125 & 13.2 \\
Sulfur content [wt\%] & $<0.2$ & variable & 5.96 \\
Iodine value [centigram I/g & & & \\
Oil] & & & \\
\hline
\end{tabular}

Table 4. Properties of the mayor types of oil

* Chhetri et al., 2008, Demirbas, 2008

+ http://globalsmartinvestment.com/SoyOil.aspx

x Zhang et al., 2003, Dmytryshyn et al., 2004, Phan \& Phan, 2008, Anastopoulos et al., 2009

\begin{tabular}{lcccc}
\hline \multirow{2}{*}{ Parameters } & \multicolumn{4}{c}{ Non Edible Oils } \\
\cline { 2 - 5 } & Jatropha & Rubber & Castor & Pongamia pinnata \\
\hline Viscosity & 4.8 & 5,81 & --- & 4.8 \\
Specific gravity & --- & 0.874 & 0.960 & --- \\
Calorific value $[\mathrm{MJ} / \mathrm{kg}]$ & 39.23 & 36.50 & 39.5 & -- \\
Flash point $\left[{ }^{\circ} \mathrm{C}\right]$ & 135 & 130 & 260 & 150 \\
Cloud point $\left[{ }^{\circ} \mathrm{C}\right]$ & --- & 4 & -12 & --- \\
Pour point $\left[{ }^{\circ} \mathrm{C}\right]$ & 2 & --- & -32 & -- \\
Ash content $[\mathrm{wt} \%]$ & 0.012 & $\ldots$ & 0.020 & 0.0005 \\
Acid value $[\mathrm{mg} \mathrm{KOH} / \mathrm{g}]$ & 0.400 & 0.118 & --- & 0.620 \\
\hline
\end{tabular}

Table 5. Properties of biodiesel from different sources. Extracted from reference (Gui et al., 2008)

Gradually, a third type of oil is bearing relevance due to a number of advantages. This third type is produced from algae. Algae are microscopic organisms which could be used for the production of different types of fuel such as biodiesel, bio-hydrogen production, methane, etc. Algae have several advantages to be used for producing biofuel, some of them are: $i$ ) they required $\mathrm{CO}_{2}$ to grow, ii) they grow in non drinkable water, not competing with drinkable sources, iii) algae could grow in land fields where no other vegetable oil could grow, iv) algae could be use as raw materials for several other chemical compounds easy to produce.

Even more, as in the case for vegetable oils, each type of algae has a percentage of oil in within. Table 6 shows some of the most common algae and the amount of oil in each of them (Chisti, 2007). 
It could be seen that this percentage varies from 15 to over $75 \%$ being the last quite suitable for producing the oil to be use in the production of biofuels.

\begin{tabular}{lc}
\hline Microalgae & Oil content (\% dry wt.) \\
\hline Botryococcus braunii & $25-75$ \\
Chlorella sp. & $28-32$ \\
Crypthecodinium cohnii & 20 \\
Cylindrotheca sp. & $16-37$ \\
Dunaliella primolecta & 23 \\
Isochrysis sp. & $25-33$ \\
Monallanthus salina & $>20$ \\
Nannochloris sp. & $20-35$ \\
Nannochloropsis sp. & $31-68$ \\
Neochloris oleoabundans & $35-54$ \\
Nitzschia sp. & $45-47$ \\
Phaeodactylum tricornutum & $20-30$ \\
Schizochytrium sp. & $50-77$ \\
Tetraselmis sueica & $15-23$ \\
\hline
\end{tabular}

Table 6. Oil content for several microalgae. Extracted from reference (Chisti, 2007).

Mata et al. (Mata et al., 2010) have done a research on how much biodiesel could be produce by growing different seeds in one ha. They work shows that, among those sources studied; corn has the lowest one production rate per year in 1 hectare (151 kg of biodiesel); sunflower oil is place in middle position with a production close to 1000 kilos per year per hectare; while microalgae are place quite high above. In regard to microalgae, they are classified depending on their oil content, which is divided into low, medium and high. The result is a production of 51.297, 86.515 and 121.104 kilos of biodiesel per year and per hectare respectively. This shows algae as an interesting new alternative source of vegetable oil for biodiesel.

So far it has been presented the difference in the vegetable oil accordingly to the quality of them as well as to be from different seeds, also it was presented a comparison among non edible oil and oil from algae. Thus, when comparing biodiesel from different sources, the nature of the vegetable oil is to be considered because of its effect over some of the major physical and chemical.

As it could be seen from Table 7 (Moser, 2009), when comparing the methyl esters from fatty acid with no double bonds, the increase in the chain length produce a higher viscosity. However, when double bonds are being considered, the viscosity tend to decrease as long as the amount of double bonds increases, this could be seen for C18:0 ME, C18:1 ME, C18:2 ME and 18:3 ME. When looking into the type of alcohol used, the longer the alcohol chain is the higher the viscosity of the biodiesel.

A similar scenario could be seen when comparing the cetane number, when the carbon chain or the alcohol chain increases, the cetane number increases as well, however, the presence of double bonds will decrease this property considerably. 


\begin{tabular}{lcccccc}
\hline FAEE & $\begin{array}{c}\text { Melting } \\
\text { point }\left({ }^{\circ} \mathbf{C}\right)\end{array}$ & $\begin{array}{c}\boldsymbol{\Delta}_{\mathbf{c}} \mathbf{H} \\
(\mathbf{M J} / \mathbf{m o l})\end{array}$ & $\begin{array}{c}\text { Kinematics } \\
\text { viscosity }\left(\mathbf{m m}^{2} / \mathbf{s}\right)\end{array}$ & $\begin{array}{c}\text { Oil stability } \\
\text { index (h) }\end{array}$ & $\begin{array}{c}\text { Cetane } \\
\text { Number }\end{array}$ & Lub (pm) \\
\hline C12:0 ME & 5 & 8.14 & 2.43 & $>40$ & 67 & 416 \\
C12:0 EE & -2 & & 2.63 & $>40$ & & \\
C14:0 ME & 19 & 10.67 & 3.30 & $>40$ & & 353 \\
C14:0 EE & 12 & & 3.52 & $>40$ & & \\
C16:0 ME & 31 & 10.67 & 4.38 & $>40$ & 86 & 357 \\
C16:0 EE & 19 & & 4.57 & & 93 & \\
C16:1 ME & -34 & 10.55 & 3.67 & 2.1 & 51 & 246 \\
C16:1 EE & -37 & & & & & \\
C18:0 ME & 39 & 11.96 & 5.85 & $>40$ & 101 & 322 \\
C18:0 EE & 32 & & 5.92 & $>40$ & 97 & \\
C18:0 BE & 28 & & 7.59 & & 92 & \\
C18:1 ME & -20 & 11.89 & 4.51 & 2.5 & 59 & 290 \\
C18:1 EE & -20 & & 4.78 & 3.5 & 68 & \\
C18:1 BE & -26 & & 5.69 & & 62 & 303 \\
C18:2 ME & -35 & 11.69 & 3.65 & 1.0 & 38 & 236 \\
C18:2 EE & & & 4.25 & 1.1 & 40 & \\
C18:3 ME & -52 & 11.51 & 3.14 & 0.2 & 23 & 183 \\
C18:3 EE & & & 3.42 & 0.2 & 27 & \\
\hline
\end{tabular}

Table 7. Properties of different biodiesel. Extracted from reference (Moser, 2009).

\section{Some about biodiesel production}

So far, it has been considered the different raw materials and the different types of oil quality. It is important to describe some of the fundamentals of biodiesel production before reflecting on selecting the appropriate technology to use. In section 5, it will be presented different technologies and how the quality of the raw material might have an effect or might be a key factor on the decision of which production alternative should be use, and which should be avoid.

Biodiesel is a renewable and alternative liquid biofuel normally produce from vegetable oils or animal fats by the transesterification reaction (see Figure 1). Not any fuel produced from vegetable oils can be called biodiesel. Therefore, there are international standards to be reached, these are, ASTM D7467, EN 14214. The European Standard EN 14214 could be seen in Table 8 (http:/ / www.astm.org, http:/ / www.cen.eu)

The transesterification reaction, when carried on with a basic homogeneous catalyst, sodium or potassium hydroxide or methoxide (Marchetti et al., 2007, Srivastava \& Prasad, 2000, Ma \& Hanna, 1999, Fukuda et al., 2001, Knothe et al., 2005, Marchetti, 2010, Vicente et al., 2004, Meng et al., 2008, Alamu et al., 2007, Dias et al., 2008), has shown great potential producing the fuel under specification in around two hours (Srivastava \& Prasad, 2000, Ma \& Hanna, 1999, Fukuda et al., 2001, Knothe et al., 2005, Marchetti, 2010). 
The major drawback of this technology is the need of refined oil which is on the hot spot due to the Fuel vs. Food debate. Due to the need of oil for feeding purposes and for biofuel production; alternative raw materials, pointed out in section 2, are being evaluated, tested and used. The uses of these new raw materials have generated new processes to carry on the transesterification reaction, example of this are: acid homogeneous catalyst (Marchetti et al., 2007, Srivastava \& Prasad, 2000, Ma \& Hanna, 1999, Fukuda et al., 2001, Knothe et al., 2005, Marchetti, 2010, Zheng et al., 2006, Canakci \& Van Gerpen, 2003 a,b), solid resins (Bajaj et al., 2010, Ranganathan et al., 2008, Antczak et al, 2009, Rodrigues et al., 2008, Dalla Rosa et al., 2008, Matassoli et al., 2008),supercritical alcohols (Demirbaş, 2002, 2003, Saka \& Kusdiana, 2001, Kusdiana \& Saka, 2001, 2004, Hawash et al., 2009, Gui et al., 2008, Kasim et al. 2009),

\begin{tabular}{|c|c|c|c|}
\hline Property & Units & Limits & Experiments \\
\hline Esters amount & $\%(\mathrm{~mol} / \mathrm{mol})$ & 96.5 & EN 14103 \\
\hline Density at $15^{\circ} \mathrm{C}$ & $\mathrm{kg} / \mathrm{m}^{3}$ & $860-900$ & $\begin{array}{l}\text { EN ISO 3675, } \\
\text { EN ISO } 12185\end{array}$ \\
\hline Kinematics Viscosity at $40^{\circ} \mathrm{C}$ & $\mathrm{mm}^{2} / \mathrm{s}$ & $3.5-$ & $\begin{array}{l}\text { EN ISO 3104, } \\
\text { ISO } 3105\end{array}$ \\
\hline Flash Point & ${ }^{\circ} \mathrm{C}$ & $120 \mathrm{~min}$ & EN ISO 3679 \\
\hline Sulfur content & $\mathrm{mg} / \mathrm{kg}$ & $10.0 \max$ & $\begin{array}{l}\text { EN ISO 20846, } \\
\text { EN ISO } 20884\end{array}$ \\
\hline Carbon residue & $\%(\mathrm{~mol} / \mathrm{mol})$ & $0.3 \max$ & EN ISO 10370 \\
\hline Cetane Number & & $51 \mathrm{~min}$ & EN ISO 5165 \\
\hline Sulfated ash & $\%(\mathrm{~mol} / \mathrm{mol})$ & $0.02 \max$ & ISO 3987 \\
\hline Water content & $\mathrm{mg} / \mathrm{kg}$ & $500 \max$ & EN ISO 12937 \\
\hline Total Contamination & $\mathrm{mg} / \mathrm{kg}$ & $24 \max$ & EN 12662 \\
\hline $\begin{array}{l}\text { Copper strip corrosion }(3 \mathrm{~h}, \\
\left.50^{\circ} \mathrm{C}\right)\end{array}$ & Degree of corrosion & 1 & EN ISO 2160 \\
\hline Oxidation stability, 110C & $\mathrm{H}$ & $6.0 \mathrm{~min}$ & EN 14112 \\
\hline Acid number & $\mathrm{mg} \mathrm{KOH} / \mathrm{g}$ & $0.50 \max$ & EN 14104 \\
\hline Iodo number & $\mathrm{g} \mathrm{I}_{2} / 100 \mathrm{~g}$ & $120 \max$ & EN 14111 \\
\hline Linolenic acid content & $\%(\mathrm{~mol} / \mathrm{mol})$ & $12.0 \max$ & EN 14103 \\
\hline Polyunsaturated methyl ester & $\%(\mathrm{~mol} / \mathrm{mol})$ & $1 \max$ & EN 14103 \\
\hline Methanol content & $\%(\mathrm{~mol} / \mathrm{mol})$ & $0.2 \max$ & EN 14110 \\
\hline MAG content & $\%(\mathrm{~mol} / \mathrm{mol})$ & $0.8 \max$ & EN 14105 \\
\hline DAG content & $\%(\mathrm{~mol} / \mathrm{mol})$ & $0.2 \max$ & EN 14105 \\
\hline TAG content & $\%(\mathrm{~mol} / \mathrm{mol})$ & $0.2 \max$ & EN 14105 \\
\hline Free Glycerol & $\%(\mathrm{~mol} / \mathrm{mol})$ & $0.02 \max$ & EN 14105, EN 14106 \\
\hline Total Glycerol & $\%(\mathrm{~mol} / \mathrm{mol})$ & $0.25 \max$ & EN 14105 \\
\hline Group I metals & $\mathrm{mg} / \mathrm{kg}$ & $5.0 \max$ & EN 14108, EN 14109 \\
\hline Group II metal & $\mathrm{mg} / \mathrm{kg}$ & $5.0 \max$ & EN 14538 \\
\hline Phosphorous content & $\mathrm{mg} / \mathrm{kg}$ & $10.0 \max$ & EN 14107 \\
\hline
\end{tabular}

Table 8. EN 14214 standard for biodiesel quality control (http:/ / www.cen.eu ) 
membrane reactors (Dubé et al. 2007, Baroutian et al., 2011, Zhu et al., 2010, Cheng et al., 2010, Cao et al., 2008), monolithic catalysts (Kolaczkowski et al., 2009, Dizge et al., 2009, Tonetto \& Marchetti, 2010), etc.

Besides the different technologies and their applicability, we would like to introduce a few thoughts in relation to the prospective future of biodiesel production. Johnston \& Holloway (Johnston \& Holloway, 2010) have compared 228 countries comparing their potential production of biodiesel. According to them, the five countries with the absolute biodiesel potential are Malaysia, Indonesia, Argentina, USA and Brazil. However, when considering the high potential of production in combination with the low production cost, the top five countries are Malaysia, Indonesia, Philippines, Papua New Guinea, and Thailand. This result is relevant to draw the attention to new possible production markets.

\section{A comparison of the different production technologies}

As mentioned before, many works have been carried on in order to find new alternative technologies to produce biodiesel from impure raw material such as crude oil, waste or cooking oil, frying oil, soapstoacks', animal fat, etc. In a typical biodiesel production flow diagram (Figure 5), a few equipments might not be needed for all the technologies available. However, to show the most general case, we have added separation and purification processes as a rule. In some cases, purification is not required, and in some other a preesterification before the transesterification reaction is needed. A more complete flow

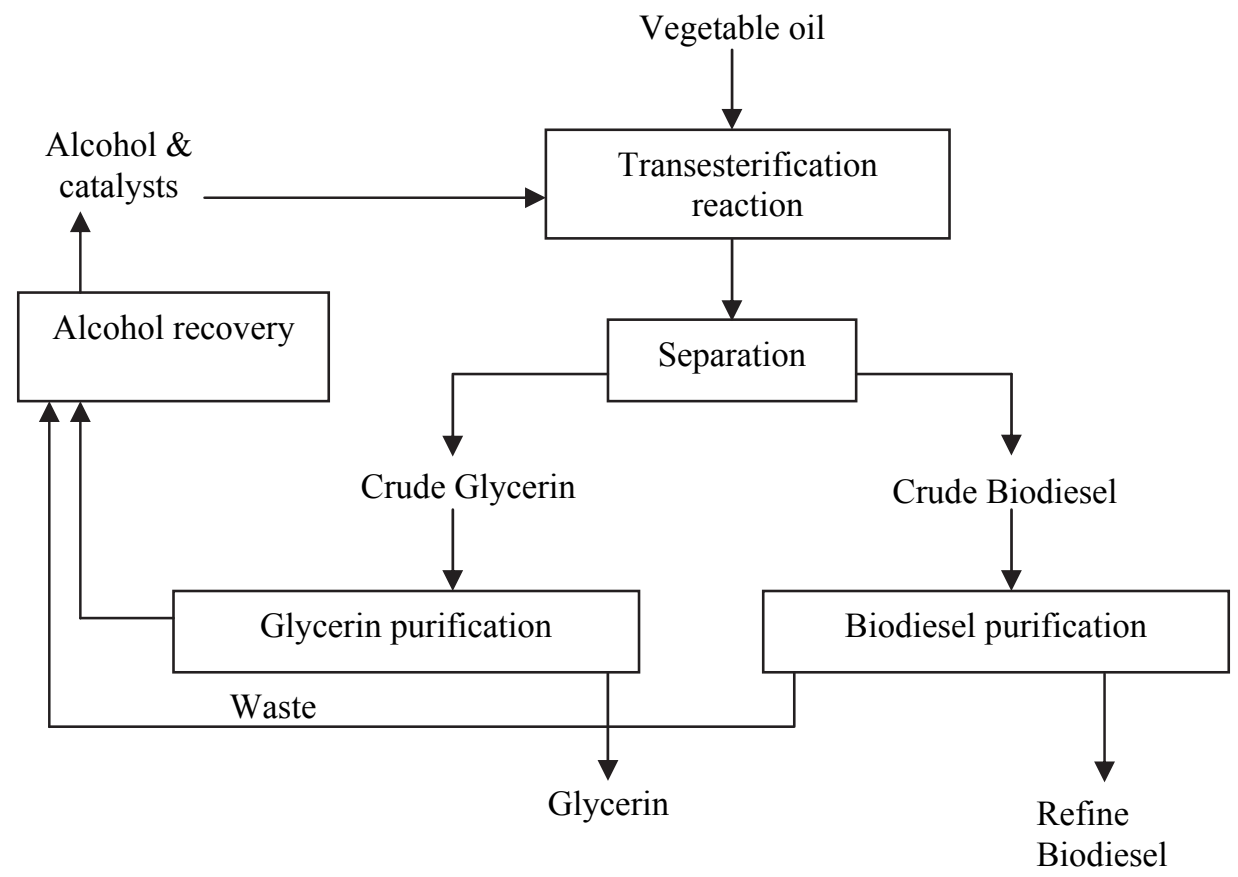

Fig. 5. Flow diagram of a conventional process (Marchetti et al., 2007). 
diagram could be seen in the work done by Balat (Balat, 2011). For a more detailed process, when algae are used, it is advisable to see the work done by Lin et al. (Linn et al, 2011).

When using a homogeneous acid catalyst, like sulfuric acid, the transesterification reaction is 4000 times slower (Srivastava \& Prasad, 2000, Ma \& Hanna, 1999, Fukuda et al., 2001, Knothe et al., 2005, Marchetti, 2010), compared with when a base homogeneous catalyst is used. Nevertheless, the esterification reaction could also take place and be carried on without generating soaps. Therefore, this catalyst allows to treat less pure raw material with some fatty acids and/or water within it (Canakci \& Van Gerpen, 2003 a,b, Marchetti \& Errazu, 2008).

On the other hand, since the catalyst is in homogeneous phase, the need of neutralization, purification, and separation, are required. As a consequences, effluents as well as non desirable by-products result; this increases the amount of energy and equipments required. Thus, a bigger initial investment is needed. Finally, it is obtained a Biodiesel of good quality and a by-product, glycerin, which is of industrial grade allowing it to be used for other purposes or to be purified until pharmaceutical grade (Van Gerpen, 2005, Marchetti \& Errazu, 2008).

In order to avoid some of the neutralization and purification equipments, the use of a heterogeneous catalyst appears to be a good brand new alternative. In this case, solid acid resins and basic solid resins could be used obtaining good results (Bournay et al., 2005, Di Serio et al., 2005, 2006, Soriano et al., 2009, Hamad et al., 2008, Suppes et al., 2004, Kulkarni et al., 2006, López et al., 2008, Cao et al, 2008). The advantages of using this catalyst appears in the final products obtained, more pure Biodiesel and glycerin;: and also, in the process itself, which required less equipment and ergo a lower investment. However, there are some disadvantages to take into account. In some cases, it is impossible to carry on the reaction in the presence of water as well as other impurities such as fatty acids. Some of these catalysts (solid resins) get deactivated with water; therefore, the raw material must be refined oil. In other situations, the catalyst could treat some amount of water and fatty acid, but the reaction time is so large that is not of industrial interest (Marchetti \& Errazu, $2010 \mathrm{~b}$ ).

Enzymes seem to be the best option, for being environmentally friendly. They are produced in the nature; they require not drastic conditions to work and it could treat some impurities in the raw material. It should be considered that reaction temperature could not be too high, otherwise the organisms will die. Some water is needed it to start the reaction, but too much water will deactivated the catalyst. This one will allow the transesterification as well as the esterification reaction to take place simultaneously. On the other side, the reaction time for both reactions could be considered as too long in comparison with other options and the price of this catalyst is extremely high, making it a very non competitive alternative (Antczak et al, 2009, Rodrigues et al., 2008, Dalla Rosa et al., 2008, Dizge et al., 2009). Because of this, new enzymes as well as new enzyme technologies are being developed in a daily basis aiming to reduce the price, improving the catalytic properties and find a way of reusing it over and over again so its price could be depreciated over time.

Nowadays, one of the fastest technologies available uses supercritical alcohols, either methanol or ethanol. In this case, the reaction temperature and reaction pressure provoke the alcohol to be in a supercritical state, and therefore, not catalyst is required. Thanks to this technology, a full conversion of non high quality oils could be reached in less than 5 minutes (Demirbaş, 2002, 2003, Saka \& Kusdiana, 2001, Kusdiana \& Saka, 2001, 2004, Hawash et al., 2009, Gui et al., 2008, Kasim et al. 2009). The absence of a catalyst allows the system to treat triglycerides, fatty acids, and water with no concerns. Even more, in order to 
reduce the amount of alcohol, some works have shown that is possible to reduce the alcohol molar ratio by increasing secondary supercritical fluids such as $\mathrm{CO}_{2}$, hexane, heptanes, propane or tetrahydrofuran, being those much cheaper (Sawangkeaw et al., 2007, Tan et al., 2010, Yin et al., 2008, Han et al., 2005). In some cases, it could be found that a catalyst could be introduced into the system (Demirbaş, 2007) making possible to achieved good final conversions without compromising the down streaming separation and purification. For this process, less equipment is required and the purity of the final biodiesel and glycerin are quite good. Nevertheless, there is a need of high temperature and pressure that implies a high operational cost and makes this technology less attractive than others. But, when considering the process with different approaches it will become more economically viable (van Kasteren \& Nisworo, 2007, Deshpande et al., 2010, Lim et al., 2009)

The use of membrane reactors as well as monolithic catalysts, and monolithic reactors are among the new options that being considered. Each of them has major advantages and disadvantages over the conventional process. The monolithic reactors (Kolaczkowski et al., 2009, Dizge et al., 2009, Tonetto \& Marchetti, 2010), produced from powder of a basic catalyst, have as major concern the leaching of the catalyst from the heterogeneous phase to the homogeneous phase. Under this circumstance, the activity o the catalyst is lost, and also there is a need of purification and separation of the products from the catalyst. However, if the leaching problem is solved, the reaction will be more environmentally friendly and the Biodiesel produced will be of better quality. Membrane reactors have been widely used for the water gas shift reaction with great results (Dubé et al. 2007, Baroutian et al., 2011, Zhu et al., 2010, Cheng et al., 2010, Cao et al., 2008). Dubé et al. (Dubé et al., 2007) used them and succeeded in producing a final product of high quality. The catalyst employed was a homogeneous basic one; so we should consider that the separation of alcohol and other compounds, from the main flow, could be quite complicated, and the general price for the membrane is sometimes too high.

In order to compare the variables previously described, we selected those that are considered to be the most relevant and presented them in Table 9, were we show them in relation to the different technologies.

Based on Table 9, we can say that in all the cases, except from the base technology will produce ester from the presence of fatty acid. However, not all of them have the same effect when water is in the system, as it is in the case of solid resin and enzyme, where water could have a negative effect. In the case of monolithic, the leaching is due to the contact with a liquid phase, that is not necessarily water, and therefore, the effects of water itself are yet unknown.

The reaction temperature is quite low for the base, acid and enzymatic process, but could be quite high for the other three options. This is one of the main reasons for the cost of the technology to be from affordable to expensive. In the case of enzymes, even though the reaction temperature is quite low, the cost of the catalyst makes the general investment significant, and in some cases, making the technology not viable.

The purification of ester, its quality, and the quality of the produced glycerin are related to the type of technology used, especially when the catalyst is in homogeneous phase. In the last case, the catalyst needs to be separated and neutralization, separation, and purification of the products are required. For all the heterogeneous as well as the non catalytic alternatives, the need of purification is simpler and the need of equipment is also lower. In the case of the monolithic reactor, the leaching problem could make this technology less 


\begin{tabular}{|c|c|c|c|c|c|c|}
\hline Variable & Base & Enzyme & Supercritical & Monolithic & Resin & Acid \\
\hline Temp. $\left[{ }^{\circ} \mathrm{C}\right]$ & $60-70$ & $30-50$ & $200-350$ & $50-180$ & $60-180$ & $50-80$ \\
\hline $\begin{array}{l}\text { Products from } \\
\text { FFA }\end{array}$ & Soaps & Esters & Esters & Esters & Esters & Esters \\
\hline Effect of Water* & $\downarrow$ & $\downarrow$ & & & $\overline{ }$ & \\
\hline Yield to ester & Normal & High & High & Normal & Good & Normal \\
\hline $\begin{array}{l}\text { Purification of } \\
\text { glycerol }\end{array}$ & Difficult & Simple & Simple & Simple & Simple & Difficult \\
\hline Reaction time+ & $1-2 \mathrm{~h}$ & $8-70 \mathrm{~h}$ & 4-10 min & $6 \mathrm{~h}$ & variable & $4-70 \mathrm{~h}$ \\
\hline $\begin{array}{l}\text { Ester } \\
\text { purification }\end{array}$ & Difficult & Simple & Simple & Simple & Simple & Difficult \\
\hline Cost & Cheapest & Expensive & Expensive & Affordable & Affordable & Cheaper \\
\hline $\begin{array}{l}\text { Amount of } \\
\text { equipment }\end{array}$ & High & Low & Low & Low & Low & High \\
\hline
\end{tabular}

Table 9. Comparison of different technologies for Biodiesel production (Marchetti, 2010)

* in this case the pointing down arrow mean that water is a draw back while the line means that the is not effect and the system will be able to treat a raw material with some amount of water. For the Enzyme case, a down arrow has been supply, in this case is important to say that is believe that some water is require for enzyme activation; however, a lot of water will produce a deactivation of the catalyst. In the case of the resin, it could be seen a down arrow as well as a line, this is due to the fact that water has different effect over different solid catalyst. In the case of the monolithic scenario, a line has been selected due to the fact that leaching it is not causing by water per se but for a non stability of the catalyst.

the reaction time set in this table is what it is most likely, however, it is important to point out that other times for the same technology could be found in the open literature

suitable due to the possibility of separation and purification. So far this problem has been presented (Tonetto \& Marchetti, 2010) but not much has been done in order to solve it; even though it is considered that this disadvantage might be easier to overcome.

In all the technologies studied, the yield for biodiesel is high, even thought in some cases this is much higher.

\section{Conclusions}

In this chapter it has been presented different types of process for biodiesel production, their advantages and disadvantages as regards the different operational variables, the different raw material qualities, and the different catalysts employed.

Due to these differences, it is not easy to select a process to use. Several operational conditions and many economic variables should be considered together with those presented in Table 9, before choosing the best alternative for each case.

About the type of vegetable oil and its quality, it is important to remember that in order not to compete with the vegetable oil for feeding purposes, the oil used is in all cases is inedible 
and/or waste oil. Due to the high amount of free fatty acid that might be present on the waste oil, some technologies are more suitable than suitable than others. That is the case of supercritical alcohols over conventional process. A combination of several options produces much more reliable and environmental friendly processes. However, in those cases, the need for a much more control over other influenciable variables is stronger. When using a vegetable oil, the availability of the oil and the proximity of the plantations is also a key factor and together with a clear local policy, such as tax reduction. This will help the biodiesel companies but at the same time, it will provoke an increase in the price of the oil directly related to the need of these raw materials.

The use of waste oils should be a must. To achieve this, several options could be used based on the key factors previously explained. The use of waste oils helps to consume pollutants, does not interfere in the Fuel vs. Food debate, and demands an environmentally friendly process.

\section{References}

Alamu, O.J., Waheed, M.A., Jekayinfa, S.O. Biodiesel production from Nigenerian palm kernel oil: effect of $\mathrm{KOH}$ concentration on yield. Energy for Sustainable Development. XI(3), (2007), 77-82.

Anastopoulos, G., Zannikou, Y., Stournas, S., Kalligeros, S. Transesterification of Vegetable Oils with Ethanol and Characterization of the Key Fuel Properties of Ethyl Esters. Energies. 2. (2009), 362-376.

Antczak, M.S., Kubiak, A., Antczak, T., Bielecki, S. Enzymatic biodiesel synthesis - key factors affecting efficiency of the process. Renewable Energy. 34. (2009), 1185-1194.

Bajaj, A., Lohan, P., Jha, P.N., Mehrotra, R. Biodiesel production through lipase catalyzed transesterification: a review. Journal of Molecular Catalysis B: Enzymatic. 62. (2010), 9-14.

Balat, M. Potential alternatives to edible oils for biodiesel production - a review of current work. Energy Conversion \& Managament. 52, (2011), 1479-1492.

Baroutian, S., Aroua, M., Raman, A.A., Sulaimna, N.M.N. A packed bed membrane reactor for production of biodiesel using activated carbon supported catalyst. Bioresource Technology. 102(2), (2011), 1095-1102.

Bournay, L., Casanave, D., Delfort, B., Hillion, G., Chodorge, J.A. New heterogeneous process for biodiesel production: A way to improve the quality and the value of the crude glycerin produced by biodiesel plants. Catalysis Today. 105, (2005), 190-192.

Canakci M, Van Gerpen J. Biodiesel production from oils and fats with high free fatty acids. Transactions of the ASAE. 44(6). (2003), 1429-1436.

Canakci M, Van Gerpen J. Biodiesel production via acid catalysis. Transactions of the ASAE. 42(5). (2003), 1203-1210.

Cao, F., Chen, Y., Zhai, F., Li, J., Wang, J., Wang, X., Wang, S., Zhu, W. Biodiesel production from high acid value waste frying oil catalyzed by superacid heteroployacid. Biotechnology and Bioengineering. 101(1), (2008), 93-100.

Cao, P., Dubé, M.A., Tremblay, A. Methanol recycling in the production of biodiesel in a membrane reactor. Fuel. 87(6), (2008), 825-833.

Cheng, L,H., yen, S.Y., Su, L.S., Chen, J. Study on membrane reactors for biodiesel production by phase behaviors of canola oil methanolysis in batch reactors. Bioresource Technology. 101(17), (2010), 6663-6668. 
Chhetri, A.B., Watts, K.C., Islam, M.R. Waste Cooking Oil as an Alternate Feedstock for Biodiesel Production. Energies. 1. (2008), 3-18.

Chisti, Y. Biodiesel from microalgae. Biotechnology Advances. 25. (2007), 294-306.

Dalai, A,K. Applications of vegetable oil derived esters as a diesel additive. Energeia. 15(6), (2004), 1-6.

Dalla Rosa, C., Morandim, M.B., Ninow, J.L., Oliveira, D., Trichel, H., Vladimir Oliveira, J. Lipase-catalyzed production of fatty acid ethyl esters from soybean oil in compressed propane. The Journal of Supercritical Fluids. 47, (2008), 49-53.

Demirbaş, A. Biodiesel from sunflower oil in supercritical methanol with calcium oxide. Energy Conversion \& Management. 48, (2007), 937-941.

Demirbaş, A. Biodiesel fuels from vegetable oils via catalytic and non catalytic supercritical alcohol transesterification and other methods: a survey. Energy Conversion and Management. 44, (2003), 2093-2109.

Demirbaş, A. Biodiesel fuels from vegetable oils via transesterification in supercritical methanol. Energy Conversion and Management. 43, (2002), 2349-2356.

Demirbas, A. Biodiesel. A Realistic Fuel Alternative for Diesel Engines. Editorial Springer 2008.

Demirbas, A. Production of Biodiesel from Algae Oils. Energy Sources, Part A: Recovery, Utilizations and Environmental Effects. 31:2. (2009), 163-168.

Deshpande, A., Anitescu, G., Rice, P.A., Tavlarides, L.L. Supercritical biodiesel production and power cogeneration: technical and economic feasibilities. Bioresource Technology. 101, (2010), 1834-1843.

Di Serio, M. Ledda, M., Cozzolino, M., Minutillo, G., Tesser, R., Santacesaria, E. Transesterification of Soybean Oil to Biodiesel Using Heterogeneous Basic Catalysts. Ind. Eng. Chem. Res. 45, (2006,) 3009-3014.

Di Serio, M., Tesser, R., Dimiccoli, M., Cammarota, F., Nastasi, M., Santacesaria, E. Synthesis of biodiesel via homogeneous Lewis acid catalyst. Journal of Molecular Catalysis A: Chemical. 239, (2005) 111-115.

Dias, J.M., Alvim-Ferraz, M.C.M, Almeida, M.F. Comparison of the performance of different homogeneous alkali catalysts during transesterification of waste and virgin oils and evaluation of biodiesel quality. Fuel. 87, (2008), 3572-3578.

Dizge, N., Aydiner, C., Imer, D.Y., Bayramoglu, M., Tanriseven, A., Keskinler, B. Biodiesel production from sunflower, soybean and waste cooking oils by transesterification using lipase immobilized onto a novel microporous polymer. Bioresource Technology. 100, (2009), 1983-1991.

Dmytryshyn, S.L., Dalai, A.K., Chaudhari, S.T., Mishra, H.K., Reaney, M.J. Synthesis and Characterization of Vegetable Oil Derived Esters: Evaluation for their Diesel Additive Properties. Bioresource Technology. 92. (2004), 55.64.

Dubé, M.A., Tremblay, A.Y., Liu, J. Biodiesel production using a membrane reactor. Bioresource Technology. 98, (2007), 639-647.

Freedman, B., Pryde, E.H., Mounts, T.L. Variables affecting the yields of fatty esters from transesterified vegetable oils. Journal of American Oil Chemists Society. 61(10). (1984), 1638-1643.

Fukuda. H., Kondo. A., Noda, H. Biodiesel fuel production by transesterification of oils. Journal of Bioscience \& Bioengineering. 92(5). (2001), 405-416.

Fuse, T., Kusu, F., Takamura, K. Determination of acid values of fats and oils by flow injection analysis with electrochemical detection. Journal of Pharmaceutical and Biomedical Analysis. 15, (1997), 1515-1519. 
Gui, M.M., Lee, K.T., Bhatia, S. Feasibility of Edible oil vs. non-edible oil vs. waste edible oil as biodiesel feedstocks. Energy. 33. (2008), 1646-1653.

Gui, M.M., Lee, K.T., Bhatia, S. Supercritical ethanol technology for the production of biodiesel: process optimization studies. The Journal of Supercritical Fluids. Doi:10.1016/j.supflu.2008.12.014.

Hamad, B., Lopes de Souza, R.O., Sapaly, G., Carneiro Rocha, M.G., Pries de Oliveira, P.G., Gonzalez, W.A., Andrade Sales, E., Essayem, N. Transesterification of rapeseed oil with ethanol over heterogeneous heteropolyacids. Catalysis Communications. 10, (2008), 9297.

Han, H., Cao, W., Zhang, J. Preparation of biodiesel from soybean oil using supercritical methanol and $\mathrm{CO}_{2}$ as co-solvent. Process Biochemistry. 40, (2005), 3148-3151.

Hawash, S., Kamal, N., Zaher, F., Kenawi, O., El Diwani, G. Biodiesel fuel from Jatropha oil via non-catalytic supercritical methanol transesterification. Fuel. 88, (2009), 579-582.

http://globalsmartinvestment.com/SoyOil.aspx

http:/ / hypertextbook.com/facts/2000/IngaDorfman.shtml

http://journeytoforever.org/biodiesel_SVO-palm.html

http://journeytoforever.org/biodiesel_yield2.html

http://journeytoforever.org/biofuel_library/fatsoils/fatsoils2.html

http://vegburner.co.uk/oils.htm

http://www.astm.org/Standards/D6751.htm

http://www.canolacouncil.org/uploads/Chemical1-6.pdf

http://www.cen.eu/cen/pages/default.aspx

http://www.diracdelta.co.uk/science/source/f/l/flash\%20point/source.html

http://www.elsbett.com/engl/oil.htm

http://www.indexmundi.com/commodities/ ?commodity=crude-oil\&months $=360$

http://www.indexmundi.com/commodities/?commodity=soybean-oil\&months $=360$

http://www.indiamart.com/company/2466820/products.html

http://www.sunflowernsa.com/oil/product-specifications/nusun-refined/

Johnston, M., Holloway, T. A global comparison of national biodiesel production potentials. Environmental Science \& Technology. 41(23), (2007), 7967-7973.

Kasim, N.S., Tsai, T.H., Gunawan, S., Ju, Y.H. Biodiesel production from rice bran oil and supercritical methanol. Bioresource Technology. 100, (2009), 2399-2403.

Knothe, G., Van Gerpen, J., Krahl, J. (Eds.), The biodiesel handbook, AOCS Press, Champaign, Illinois, 2005, $302 \mathrm{pp}$.

Kolaczkowski, S.T., Asli, U.A., Davidson, M.G. A new heterogeneous $\mathrm{ZnL}_{2}$ catalyst on a structured support for biodiesel production. Catalysis Today. 147(1), (2009), S220-S224.

Kulkarni, M.G., Gopinath, R., Meher, L.C., Dalai, A.K. Solid acid catalyzed biodiesel production by simultaneous esterification and transesterification. Green Chemistry. 8, 1056-1062, 2006.

Kusdiana, D., Saka, S. Effects of water on biodiesel fuel production by supercritical methanol treatment. Bioresource Technology. 91, (2004), 289-295.

Kusdiana, D., Saka, S. Kinetics of transesterification in rapeseed oil to biodiesel fuel as treated in supercritical methanol. Fuel. 80, (2001), 693-698.

Lim, Y., Lee, H.S., Lee, Y.W., Han, C. Design and economic analysis of the process for biodiesel fuel production from transesterificated rapeseed oil using supercritical methanol. Industrial \& Engineering Chemistry Research. 48, (2009), 5370-7378. 
Lin, L., Cunshan, Z., Vittayapadung, S., Xiangqian, S., Mingdong, D. Opportunities and challenges for biodiesel fuel. Applied Energy. 88, (2011), 1020-1031.

López, D.E., Goodwin Jr., J.G., Bruce, D.A., Furuta, S. Esterification and transesterification using modified zirconia catalysts. Applied Catalysis A: General. 339, (2008), 76-83.

Ma F. Hanna MA.. Biodiesel production: A review. Bioresource Technology. 70. (1999), 1-15.

Marchetti, J.M. Biodiesel Production Technologies. Nova Publishers. (2010). New York, New York.

Marchetti, J.M., Errazu, A.F. Biodiesel production from acid oils and ethanol using a solid basic resin as catalyst. Biomass \& Bioenergy. 34(3), (2010), 272-277.

Marchetti, J.M., Errazu, A.F. Esterification of free fatty acids using sulfuric acid as catalyst in the presence of triglycerides. Biomass \& Bioenergy. 32, (2008), 892-895.

Marchetti, J.M., Miguel, V.U., Errazu, A.F. Techno-economic study of different alternatives for biodiesel production. Fuel Processing Technology. 89, (2008), 740-748.

Marchetti. J.M.. Miguel. V.U.. Errazu. A.E. Possible methods for biodiesel production. Renewable and Sustainable Energy Reviews. 11. (2007), 1300-1311.

Mata, T.M., Martins, A.A., Caetano, N.S. Microalgae for biodiesel production and other applications: A review. Renewable and Sustainable Energy Reviews. 14. (2010), 217232.

Matassoli, A.L.F., Corrêa, I.N.S, Portillo, M.F., Veloso, C.O., Langone, M.A.P. Enzymatic synthesis of biodiesel via alcoholysis of palm oil. Applied Biochemistry \& Biotechnology. 155, (2008), 44-52.

Meng, X., Chen, G., Wang, Y. Biodiesel production from waste cooking oil via alkali catalyst and its engine test. Fuel Processing Technology. 89, (2008), 851-857.

Moser, B.R. Biodiesel production, properties and feedstocks. In Vitro Cellular and Developmental Biology - Plants. 45. (2009), 229-266.

Noureddini, H., Zhu, D. Kinetics of transesterification of soybean oil. Journal of American Oil Chemists Society. 74(11). (1997), 1457-1463.

O'Brien, R., Farr, W., Wan, P. Editors. Introduction to Fats and Oils Technology: Second Edition, 2000. Editorial AOCS.

Phan, A.N., Phan, T.M. Biodiesel Production from Waste Cooking Oils. Fuel, 87. (2008), 34903496.

Purdy, R.H. High oleic sunflower: Physical and chemical characteristics. Journal of American Chemists Society. 63(8), (1986), 1062-1066.

Ranganathan, S.V., Narasimhan, S.L., Muthukumar, K. An overview of enzymatic production of biodiesel. Bioresource Technology. 99. (2008), 3975-3981.

Rodrigues, R.C., Volpato, G., Wada, K., Ayub, M.A.Z. Enzymatic synthesis of biodiesel from transesterification reactions of vegetble oils and short chaing alcohols. Journal of American oil Chemists Society. 85, (2008) 925-930.

Saka, S., Kusdiana, D. Biodiesel fuel from rapeseed oil as prepared in supercritical methanol. Fuel. 80, (2001), 225-231.

Sawangkeaw, R., Bunyakiat, K., Ngamprasertsith, S. Effect of co-solvents on production of biodiesel via transesterification in supercritical methanol. Green Chemistry. 9, (2007), 679-685.

Schuchardt, U., Sercheli, R., Vargas, R.M. Transesterification of vegetable oils: a review. JBCS, 9(1). (1998), 199-210. 
Soriano Jr, N.U., Venditti, R., Argyropoulos, D.S. Biodiesel synthesis via homogeneous Lewis acid-catalyzed transesterification. Fuel. 88, (2009) 560-565.

Srivastava A. Prasad R.. Triglycerides-based diesel fuels. Renewable Sustainable Energy Reviews. 4. (2000), 111-133.

Suppes, G.J., Dasari, M.A., Doskocil, E.J., Mankidy, P.J., Goff, M.J. Transesterification of soybean oil with zeolite and metal catalysts. Applied Catalysis A: General 257, (2004), 213-223.

Tan, K.T., Lee, K.T., Mohamed, A.R. Effects of free fatty acids, water content and co-solvent on biodiesel production by supercritical methanol reaction. The Journal of Supercritical Fluids. 53, (2010), 88-91.

Tonetto, G.M., Marchetti, J.M. Transesterification of soybean oil over $\mathrm{Me} / \mathrm{Al}_{2} \mathrm{O}_{3}(\mathrm{Me}=\mathrm{Na}, \mathrm{Ba}, \mathrm{Ca}$,

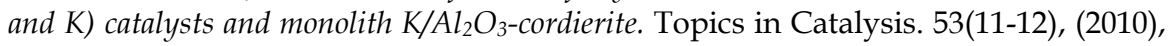
755-762.

Van Gerpen, J. Biodiesel processing and production. Fuel Processing Technology. 86, (2005), 1097-1107.

van Kasteren, J.M.N, Nisworo, A.P. A process model to estimate the cost of industrial scale biodiesel production from waste cooking oil by supercritical transesterification. Resources, Conservation and Recycling. 50, (2007), 442-458.

Vicente, G., Martínes, M., Aracil, J. Integrated biodiesel production: a comparison of different homogeneous catalysts systems. Bioresource Technology. 92, (2004), 297-305.

Yin, J.Z., Xiao, M., Song, J.B. Biodiesel from soybean oil in supercritical methanol with co-solvent. Energy Conversion \& Management. 49, (2008), 908-912.

Zhang, Y., Dubé, M.A., McLean, D.D., Kates, M. Biodiesel production from waste cooking oil: 2 Economic assessment and sensitivity analysis. Bioresource Technology. 90. (2003), 229240.

Zheng, S., Kates, M., Dubé, M.A., McLean, D.D. Acid-catalyzed production of biodiesel form waste frying oil. Biomass \& Bioenergy. 30(3). (2006), 267-272.

Zhu, M., He, B., Shi, W., Feng, Y., Ding, J., Li, J., Zeng, F. Preparation and characterization of PSSA/PVA catalytic membrane for biodiesel production. Fuel. 89(9), (2010), 2299-2304. 


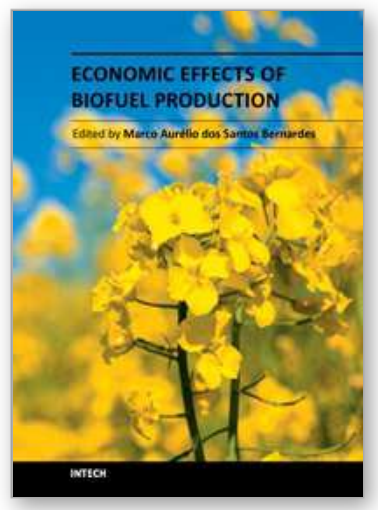

\author{
Economic Effects of Biofuel Production \\ Edited by Dr. Marco Aurelio Dos Santos Bernardes
}

ISBN 978-953-307-178-7

Hard cover, 452 pages

Publisher InTech

Published online 29, August, 2011

Published in print edition August, 2011

This book aspires to be a comprehensive summary of current biofuels issues and thereby contribute to the understanding of this important topic. Readers will find themes including biofuels development efforts, their implications for the food industry, current and future biofuels crops, the successful Brazilian ethanol program, insights of the first, second, third and fourth biofuel generations, advanced biofuel production techniques, related waste treatment, emissions and environmental impacts, water consumption, produced allergens and toxins. Additionally, the biofuel policy discussion is expected to be continuing in the foreseeable future and the reading of the biofuels features dealt with in this book, are recommended for anyone interested in understanding this diverse and developing theme.

\title{
How to reference
}

In order to correctly reference this scholarly work, feel free to copy and paste the following:

Jorge Mario Marchetti (2011). A Comparison Between Raw Material and Technologies for a Sustainable Biodiesel Production Industry, Economic Effects of Biofuel Production, Dr. Marco Aurelio Dos Santos Bernardes (Ed.), ISBN: 978-953-307-178-7, InTech, Available from:

http://www.intechopen.com/books/economic-effects-of-biofuel-production/a-comparison-between-raw-materialand-technologies-for-a-sustainable-biodiesel-production-industry

\section{INTECH}

open science | open minds

\author{
InTech Europe \\ University Campus STeP Ri \\ Slavka Krautzeka 83/A \\ 51000 Rijeka, Croatia \\ Phone: +385 (51) 770447 \\ Fax: +385 (51) 686166 \\ www.intechopen.com
}

\author{
InTech China \\ Unit 405, Office Block, Hotel Equatorial Shanghai \\ No.65, Yan An Road (West), Shanghai, 200040, China \\ 中国上海市延安西路65号上海国际贵都大饭店办公楼405单元 \\ Phone: +86-21-62489820 \\ Fax: +86-21-62489821
}


(C) 2011 The Author(s). Licensee IntechOpen. This chapter is distributed under the terms of the Creative Commons Attribution-NonCommercialShareAlike-3.0 License, which permits use, distribution and reproduction for non-commercial purposes, provided the original is properly cited and derivative works building on this content are distributed under the same license. 